\title{
Analiza stanu techniczno-prawnego instalacji gazowych w Polsce pod względem bezpieczeństwa ich eksploatacji - propozycje zmian
}

\begin{abstract}
Pomimo dostępnych na rynku zabezpieczeń instalacji gazowych oraz materiałów stosowanych do budowy tych instalacji, często wykorzystywanych już w krajach UE oraz USA [1], przepisy obowiązujące w Polsce nie zawsze pozwalają swobodnie z nich korzystać. Obowiązujący w Polsce system prawny poddany został analizie pod kątem bezpieczeństwa eksploatacji urządzeń i instalacji gazowych, stosowania zabezpieczeń dostępnych na rynku oraz możliwości użycia nowych materiałów do budowy instalacji gazowych. Przedstawiono propozycję zmian systemowych, które wprowadziłyby możliwość stosowania tych rozwiązań, pozwalających zwiększyć bezpieczeństwo eksploatacji instalacji gazowych.
\end{abstract}

Słowa kluczowe: zabezpieczenia instalacji, instalacja gazowa, butle gazowe, bezpieczeństwo.

\section{Analysis of technical and legal status of operation of gas installations in Poland in terms of safety - proposals for changes}

\begin{abstract}
Despite the commercially available security of gas installations and materials used to build them, often already applied in the EU and the US [1], the provisions in force in Poland does not always allow you to freely use them. The legal system in force in Poland has been analyzed for the safety of the operation of gas appliances and installations, the use of securities available on the market and the possibility of using new materials for the construction of gas installations. A proposal of systemic changes that would introduce the possibility of applying these arrangements, which allow to increase the operational safety of gas installations.
\end{abstract}

Key words: security system, gas installation, gas cylinder (gas bottles), safety.

\section{Analiza stanu techniczno-prawnego nowoczesnych technik zabezpieczających w Polsce pod kątem możliwości ich zastosowania}

Na wstępie przeanalizowano zapisy Polskiej Normy PN-EN 1775:2009 Dostawa gazu - Przewody gazowe dla budynków - Maksymalne ciśnienie robocze równe 5 bar lub mniejsze - Zalecenia funkcjonalne [5] i porównano ją z innymi przepisami obowiązującymi w Polsce.

Norma ta określa ogólne zalecenia dotyczące projektowania, budowy, prób, odbioru, uruchomienia, użytkowania i obsługi instalacji gazowej pomiędzy punktem dostawy gazu a złączem przy odbiorniku gazu. W niniejszej pracy przytoczono kilka najważniejszych zapisów tej normy. Zgodnie $\mathrm{z}$ nimi elementy składowe, $\mathrm{z}$ jakich zbudowana jest instalacja gazowa, powinny być dostosowane do:
- rodzaju rozprowadzanych gazów,

- ciśnienia projektowanego w instalacji,

- lokalizacji przewodów gazowych,

- temperatury przewodów gazowych w normalnych warunkach pracy,

- środowiska potencjalnie korozyjnego.

Ponadto projektant powinien tak zaprojektować instalację, aby w przypadku wystąpienia pożaru w budynku wyposażonym w instalację gazową zminimalizować prawdopodobieństwo wybuchu lub rozprzestrzeniania się pożaru. W punkcie 4.4 normy podano przykłady rozwiązań, jakie można zastosować, aby temu zapobiec: 
- odcięcie przewodów gazowych za pomocą armatury odcinającej zamykanej ręcznie,

- odcięcie przewodów gazowych za pomocą armatury odcinającej zamykanej automatycznie,

- użycie materiałów, części składowych oraz połączeń odpornych na działanie wysokich temperatur,

- umieszczenie całości przewodów gazowych lub ich części w odpowiedniej obudowie, zapewniającej ochronę na wypadek pożaru,

- pokrycie przewodów gazowych odpowiednim materiałem ochronnym, który sprawia, że przewody te są w stanie wytrzymać wysokie temperatury przez ustalony czas. Natomiast w punkcie 4.6 normy Urzadzenia zabezpieczajace, podpunkt 4.6.3, zapisano: ,Jeżeli tak wynika z oceny ryzyka, należy zainstalować dodatkowe zabezpieczenie w celu ochrony przed skutkami uszkodzenia jakiegokolwiek elementu przewodów gazowych" [5].

Tak więc po przeprowadzeniu oceny ryzyka norma wręcz narzuca konieczność wykonania dodatkowych zabezpieczeń, gdy istnieje ryzyko wystąpienia pożaru, uszkodzenia instalacji czy nagłego rozszczelnienia. Może to być np. zamontowanie urządzeń zabezpieczających przed wzrostem temperatury i wzrostem przepływu lub obudowanie przewodów gazowych. Doboru takich urządzeń w zależności od stopnia ryzyka, mocy urządzeń gazowych i spadków ciśnień w instalacji powinien dokonać projektant instalacji gazowej.

Jak widać z powyższych zapisów, dopuszczone jest wykorzystanie tzw. automatycznych zaworów odcinających, reagujących na wzrost przepływu gazu. Sama norma dotyczy instalacji pracujących pod ciśnieniem do 5 bar. W przypadku zastosowania wyższych ciśnień niż obecnie w Polsce (np. jak we Francji) zadziałanie zaworu reagującego na zwiększony przepływ jest szybsze i pewniejsze.

W punkcie 5 Budowa oraz kolejnych podpunktach w normie pojawiają się zapisy dotyczące materiałów, połączeń, armatury odcinającej, przejść przez ściany budynków i przewodów podłączeniowych urządzenia.

Powyższa norma dopuszcza stosowanie różnych połączeń, między innymi [5]:

- gwintowanych - połączenia gwintowane powinny być zgodne z EN 10226-1 lub PN-EN 10226-2 - połączenia gwintowane dopuszczalne są tylko w przypadku rur o średnicy do DN 50. Rurowe kształtki gwintowane mogą być wykonane z żeliwa ciągliwego, stali, miedzi lub stopów miedzi;

- spawanych, lutowanych twardo lub miękko, zgrzewanych - przewodnik ich wykonania opisany został w powyższej normie.

Uwaga: W rozporządzeniu Ministra Infrastruktury i Rozwoju z dnia 17 lipca 2015 r. w sprawie warunków tech- nicznych, jakim powinny odpowiadać budynki i ich usytuowanie [4], w $\S 163$, zapisano: ,[...] przewody instalacji gazowej powinny być wykonane [...] lub z rur miedzianych łączonych przez lutowanie lutem twardym". W celu uściślenia tego sformułowania (lut twardy rozpoczyna się od temperatury $450^{\circ} \mathrm{C}$ ) proponuje się je uzupełnić o następujący zapis: „o temperaturze samozapłonu gazu”; - mechanicznych - połączenia, które uzyskuje się poprzez zaciskanie, z użyciem lub bez użycia uszczelki, które może być demontowane i ponownie montowane;

- zaciskowych - wykonywane przy użyciu narzędzi, z zastosowaniem uszczelki typu O-ring, powinny być odporne na siły działające na przewody, np. rozciąganie, zginanie, skręcanie. Połączenia mogą być wykonywane na rurach miedzianych, wielowarstwowych z PE lub PEX;

- systemu łączenia falistych przewodów rurowych giętkich ze stali nierdzewnej - system ten zbudowany jest z rur stalowych falistych i złączek (kształtek mechanicznych). Nie obejmuje przewodów podłączeniowych urządzeń odbiorczych.

W kolejnym punkcie normy 5.3 istnieje zapis dotyczący przejścia instalacji gazowej przez ściany i stropy. Wynika z niego, że przewody gazowe powinno się umieszczać w rurach osłonowych, których co najmniej jeden koniec jest otwarty.

W przypadku armatury odcinającej (punkt 5.5 normy) kurki kulowe sterowane ręcznie powinny spełniać wymagania normy PN-EN 331 i obecnie mogą być stosowane do średnicy DN 100. Zaleca się również, aby armatura odcinająca zainstalowana była w miejscach, które umożliwiają zamknięcie dopływu gazu, kiedy zajdzie taka potrzeba. Armaturę odcinającą należy zamontować przed gazomierzem, a jeśli występuje reduktor ciśnienia, to przed reduktorem. Możliwość zamknięcia dopływu gazu powinna być również możliwa przed każdym urządzeniem odbiorczym.

Elastyczne przewody podłączeniowe urządzeń gazowych powinny mieć na stałe zamontowane końcówki złączne. W przypadku zastosowania przewodów z tzw. szybkozłączem gazowym końcówka powinna być samouszczelniająca i powinna zapewnić zamknięcie dopływu gazu od strony zasilania.

W sytuacjach awaryjnych, o których mowa w punkcie 8.3.3 normy [5], przewidziano następujące kroki: „Jeżeli zostanie wykryta obecność gazu, należy":

- podjąć działania zapobiegające pojawieniu się płomienia, - odciąć dopływ gazu, jeżeli jest to możliwe, w punkcie na zewnątrz zagrożonego obszaru,

- jak najszybciej wentylować i kontrolować stężenie gazu w atmosferze.

Wprowadzona do Polski norma EN 1775 (jako PN-EN 1775) dopuszcza stosowanie instalacji z rur stalowych, miedzianych, wielowarstwowych z PE lub PEX, polietylenu czy rur 
falistych ze stali nierdzewnej, jednak szczegółowe przepisy dotyczące wykonania instalacji gazowych określane są przez dodatkowe regulacje danego kraju.

W Polsce w tym zakresie obowiązuje akt wyższej rangi, tj. rozporządzenie Ministra Infrastruktury w sprawie warunków technicznych, jakim powinny odpowiadać budynki i ich usytuowanie, w szczególności rozdział $7 \mathrm{w}$ dziale IV pt.: Instalacja gazowa na paliwa gazowe [4], w którym określono warunki, jakim powinny odpowiadać instalacje gazowe stosowane w budynkach mieszkalnych.

W § 157 ust. 1 jest zapis, który mówi: „W przewodach gazowych, doprowadzających gaz do zewnętrznej ściany budynku mieszkalnego, zamieszkania zbiorowego, użyteczności publicznej i rekreacji indywidualnej, nie powinno być ciśnienia wyższego niż $500 \mathrm{kPa}$, a do ścian zewnętrznych pozostałych budynków wyższego niż $1600 \mathrm{kPa}$ ".

Jednak ust. 2, brzmiący: „Instalacja gazowa w budynku powinna zapewniać doprowadzenie paliwa gazowego w ilości odpowiadającej potrzebom użytkowym oraz odpowiednią wartość ciśnienia przed urządzeniami gazowymi, zależną od rodzaju paliwa gazowego zastosowanego do zasilania budynku, określoną Polską Normą dotyczącą paliw gazowych, przy czym ciśnienie to nie powinno być wyższe niż $5 \mathrm{kPa}$, ogranicza ciśnienie w instalacjach wewnątrz budynków mieszkalnych do $5 \mathrm{kPa}$.

W § 158 ust. 1 wprowadzono zapis: „Instalacje sygnalizujące niedopuszczalny poziom stężenia gazu mogą być stosowane w budynkach, w których jest ustanowiony stały nadzór, zapewniający podejmowanie działań zaradczych, a także w budynkach jednorodzinnych" [4].

$\mathrm{Z}$ przepisu tego wynika, że stosowanie sygnalizacji jest niedopuszczalne w budynkach wielorodzinnych, gdzie nie ma stałego nadzoru. Należy zadać sobie pytanie, czy bezpieczniejszy jest brak sygnalizacji, czy zastosowanie sygnalizacji pomimo braku osoby nadzorującej. W przypadku uruchomienia sygnalizacji alarmowej ktokolwiek z mieszkańców może powiadomić odpowiednie służby czy administratora budynku.

Kolejne części rozporządzenia doprecyzowują, kiedy można stosować sygnalizację:

- ust. 2: „Czujki sygnalizujące niedopuszczalny poziom stężenia gazu w budynkach, o których mowa w ust. 1, powinny być instalowane w piwnicach i suterenach oraz w pomieszczeniach, w których istnieje możliwość nagromadzenia gazu przy stanach awaryjnych instalacji lub przyłącza gazowego";

- ust. 3: „Sygnały alarmowe stanu zagrożenia wybuchem w budynkach, z wyłączeniem budynków jednorodzinnych, powinny być kierowane do służb lub osób zobowiązanych do podjęcia skutecznej akcji zapobiegawczej”;
- ust. 4: „Zabrania się instalowania urządzeń sygnalizacyjno-odcinających dopływ gazu do części mieszkalnej budynku wielorodzinnego. Nie dotyczy to indywidualnych urządzeń sygnalizacyjno-odcinających dopływ gazu do odrębnych mieszkań" - z zapisu tego wynika, że zabezpieczenie wewnętrznej instalacji gazowej od kurka głównego do poszczególnych gazomierzy jest niemożliwe;

- ust. 5: „Urządzenia sygnalizacyjno-odcinające dopływ gazu należy stosować w tych pomieszczeniach, w których łączna nominalna moc cieplna zainstalowanych urządzeń gazowych jest większa niż $60 \mathrm{~kW}$ ";

- ust. 6: „Zawór odcinający dopływ gazu do budynku, będący elementem składowym urządzenia sygnalizacyjno-odcinającego, powinien być instalowany poza budynkiem, między kurkiem głównym a wprowadzeniem przewodu do budynku" [4].

Z tego i poprzednich zapisów wynika, że zamontowanie automatycznego elektrozaworu odcinającego dopływ gazu do budynku możliwe jest tylko w celu odcięcia dopływu gazu do kotłowni czy pomieszczeń technicznych budynku wielorodzinnego, zapisy nie zakazują natomiast stosowania powyższych rozwiązań w budynkach jednorodzinnych.

$\mathrm{W}$ przypadku rozszczelnienia instalacji wewnętrznej w budynku wielorodzinnym (nie w mieszkaniu) bez zastosowania automatycznego zaworu odcinającego zamontowanego np. za kurkiem głównym nie nastąpi zamknięcie dopływu gazu. Może to doprowadzić np. do wybuchu nagromadzonego gazu.

W analogicznej sytuacji, ale w przypadku, gdy zamontowany został elektrozawór za kurkiem głównym, nastąpi zadziałanie systemu alarmowego i zamknięcie dopływu gazu do budynku. Ponowne otwarcie dopływu gazu może nastąpić po ręcznym jego odblokowaniu. W tym przypadku przed odblokowaniem zaworu również należy poinformować wszystkich mieszkańców o konieczności zamknięcia zaworów przy urządzeniach gazowych, a po odblokowaniu elektrozaworu odpowietrzyć instalację gazową w każdym mieszkaniu - powinna to zrobić osoba do tego upoważniona. Zapis powyższy wiąże się z tym, że w starych budynkach mogą być jeszcze zamontowane kuchenki gazowe bez zabezpieczeń przeciwwypływowych gazu. W budynkach nowo budowanych lub w których w wyniku kontroli stwierdza się, że zamontowane są urządzenia spełniające aktualne normy, zagrożenie powyższe nie występuje - nie ma zagrożenia wycieku gazu w przypadku odblokowania instalacji gazowej budynku.

Treść § 162 [4] mówi o tym, że urządzenia redukcyjne mogą być stosowane tylko na zewnątrz budynków. Uniemożliwia to wykorzystanie w Polsce takiego systemu jak np. we Francji, z instalacją o wyższym ciśnieniu (znacznie przekraczającym $5 \mathrm{kPa}$ ) i zastosowaniem reduktorów przed urządzeniem spalającym gaz. 
Ponadto rozporządzenie [4] nie zezwala na użycie rur wielowarstwowych lub rur falistych ze stali nierdzewnej do budowy instalacji gazowych, które dopuszczone są w normie PN-EN 1775:2009. Połączenia takie są już stosowane w innych krajach, a analiza możliwości ich wykorzystania pod względem bezpieczeństwa czy wytrzymałości mechanicznych została przeprowadzona w innych opracowaniach [3].

Wynika to z zapisów podanych w $\S 163$ ust. 2 rozporządzenia [4], które pozwalają na wykonanie instalacji, począwszy od kurka głównego na zewnątrz budynku do kurków odcinających przed gazomierzami, a następnie prowadzonych do lokali mieszkalnych lub do lokali użytkowych, tylko z rur stalowych bez szwu lub z rur stalowych ze szwem przewodowym łączonych przez spawanie. Ust. 4 dopuszcza wykonanie instalacji w budynkach jednorodzinnych, budynkach w zabudowie zagrodowej oraz budynkach rekreacji indywi- dualnej, a w pozostałych budynkach przewodów za gazomierzami lub odgałęzieniami prowadzącymi do odrębnych mieszkań lub lokali użytkowych - z rur stalowych łączonych za pomocą połączeń gwintowanych lub z rur miedzianych łączonych przez lutowanie lutem twardym. Dopuszcza się również inne sposoby łączenia tych rur, spełniające wymagania Polskiej Normy, np. połączenia zaciskowe.

W omawianym rozporządzeniu [4] nie ma również zapisów mówiących o ewentualnej konieczności stosowania detektorów wykrywających tlenek węgla czy gaz w pomieszczeniach mieszkalnych, w których znajdują się urządzenia spalające paliwa gazowe. Pracownicy Instytutu Nafty i Gazu - Państwowego Instytutu Badawczego prowadzą badania nad bezpieczeństwem użytkowania urządzeń gazowych, ich prawidłową pracą i opracowaniem odpowiednich wytycznych w tym zakresie [2].

\section{Propozycja rozwiązań systemowych podnoszących poziom bezpieczeństwa instalacji gazowych w Polsce}

Ważnym problemem nieporuszanym w rozporządzeniu [4] jest migracja, przenikanie gazów do wnętrza budynków. W związku z tym proponuje się wprowadzić do tego rozporządzenia dodatkowe zapisy $\mathrm{w} \S 11$, które mogłyby zwiększyć bezpieczeństwo związane z przenikaniem gazu do wnętrza budynków.

W § 11 ust. 1 zapisano, co następuje: „Budynek z pomieszczeniami przeznaczonymi na pobyt ludzi powinien być wznoszony poza zasięgiem zagrożeń i uciążliwości określonych w przepisach odrębnych, przy czym dopuszcza się wznoszenie budynków w tym zasięgu pod warunkiem zastosowania środków technicznych zmniejszających uciążliwości poniżej poziomu ustalonego w tych przepisach bądź zwiększających odporność budynku na te zagrożenia i uciążliwości, jeżeli nie jest to sprzeczne z warunkami ustalonymi dla obszarów ograniczonego użytkowania, określonych w przepisach odrębnych" [4].

Ust. 2 brzmi: „Do uciążliwości, o których mowa w ust. 1, zalicza się w szczególności:

1) szkodliwe promieniowanie i oddziaływanie pól elektromagnetycznych,

2) hałas i drgania (wibracje),

3) zanieczyszczenie powietrza,

4) zanieczyszczenie gruntu i wód,

5) powodzie i zalewanie wodami opadowymi,

6) osuwiska gruntu, lawiny skalne i śnieżne,

7) szkody spowodowane działalnością górniczą" [4].

Do wyżej wymienionych „uciążliwości” proponuje się dopisanie dodatkowego punktu:

8) przenikanie paliw gazowych do wnętrza budynków wybudowanych poniżej poziomu gruntu.
W rozdziale $4 \mathrm{w}$ dziale VIII, mówiącym o ochronie przed zawilgoceniem i korozją biologiczną, w $\S 316$ ust. 1, którego treść brzmi: „Budynek posadowiony na gruncie, na którym poziom wód gruntowych może powodować przenikanie wody do pomieszczeń, należy zabezpieczyć za pomocą drenażu zewnętrznego lub w inny sposób przed infiltracją wody do wnętrza oraz zawilgoceniem" [4], proponuje się dopisać: „,i przed możliwością przenikania gazu”.

Podobnie do § 317 ust. 1, brzmiącego: „Ściany piwnic budynku oraz stykające się z gruntem inne elementy budynku, wykonane z materiałów podciągających wodę kapilarnie, powinny być zabezpieczone odpowiednią izolacją przeciwwilgociową” [4], proponuje się dopisać: „która dodatkowo powinna zabezpieczyć budynek przed przenikaniem gazu".

Także $\S 318$ proponuje się uzupełnić o ust. 2, w brzmieniu: „Przejścia przez przegrody zewnętrzne zlokalizowane poniżej poziomu gruntu powinny być uszczelnione", oraz dodatkowo zapis ten rozszerzyć o: „, , wyposażone w elementy odgazowujące wyprowadzone ponad poziom terenu".

Powyższe propozycje spowodowałyby konieczność wprowadzenia w projektach zastosowania dodatkowych zabezpieczeń przy wykonywaniu przepustów przez ściany czy fundamenty poniżej poziomu gruntu.

W dalszej części artykułu omówiono rozwiązania dotyczące użytkowania paliw gazowych płynnych (propan-butan).

W przepisach rozporządzenia Ministra Spraw Wewnętrznych i Administracji w sprawie warunków technicznych użytkowania budynków mieszkalnych [6], w rozdziale 14 pt.: Użytkowanie instalacji gazowej zasilanej gazem ptynnym, zapisano wymagania co do czynności, jakie należy wykonać 
po remoncie lub wymianie instalacji oraz butli na gaz propan-butan.

Zapisy § 48 mają następujące brzmienie:

- ust. 1: „Instalacja gazowa zasilana gazem płynnym, w której długość nieelastycznego przewodu z rury stalowej przekracza 2,0 m, powinna być, po jej wymianie lub remoncie, poddana głównej próbie szczelności, o której mowa w $\S 44$ ";

- ust. 2: „Instalacja gazowa zasilana z butli gazowej, w której długość przewodu nieelastycznego z rury stalowej nie przekracza 2,0 m, powinna być, po jej wymianie lub remoncie, poddana sprawdzeniu szczelności pod ciśnieniem roboczym gazu";

- ust. 3: „Sprawdzenie, o którym mowa w ust. 2, powinno być wykonywane niezwłocznie po każdej wymianie butli gazowej oraz po wymianie przewodu, o którym mowa w $\S 49$ ";

- ust. 4: „Sprawdzenie szczelności przy wymianie butli gazowej przeprowadza użytkownik instalacji, zgodnie $\mathrm{z}$ instrukcją otrzymaną od rozprowadzającego butle, lub przedstawiciel dostawcy gazu, w przypadku gdy z użytkownikiem lokalu została zawarta umowa o dostarczanie gazu w butlach" [6].

W związku z powtarzającymi się przypadkami nieprawidłowego montażu butli gazowych, brakiem kontroli szczelności, niewłaściwym użytkowaniem i przechowywaniem butli należałoby zaproponować dodatkowe zapisy, które mogłyby poprawić bezpieczeństwo użytkowania paliw płynnych (propan-butan), szczególnie stosowania butli $11 \mathrm{~kg}$.

W ust. 4 proponuje się zmienić zapis na: „Sprawdzenie szczelności przy wymianie butli gazowej przeprowadza na wniosek użytkownika instalacji osoba upoważniona, posiadająca odpowiednie kwalifikacje, lub przedstawiciel dostawcy gazu, w przypadku gdy z użytkownikiem lokalu została zawarta umowa o dostarczanie gazu w butlach".

W § 50, którego ust. 1 pkt 5 brzmi: „po każdej wymianie butli w baterii należy sprawdzić szczelność połączeń zgodnie $\mathrm{z}$ warunkami określonymi w instrukcji użytkowania tej baterii”, również należałoby zmienić zapis ust. 2 na: „Sprawdzenie, o którym mowa w ust. 1 pkt 5, przeprowadza na wniosek użytkownika instalacji osoba upoważniona, posiadająca odpowiednie kwalifikacje, lub przedstawiciel dostawcy gazu, jeżeli wynika to z umowy o dostarczanie gazu płynnego".

Można również rozważyć konieczność sporządzenia odpowiedniego pokwitowania/protokołu ze sprawdzenia szczelności połączeń po montażu butli gazowej oraz konieczność zamontowania czujnika gazu propan-butan z sygnalizacją akustyczną.

Osoba montująca butlę, sprawdzająca szczelność połączeń, mogłaby odmówić wykonania montażu butli w przypadku, gdy:
- upłynęła data ważności przewodu, o której mowa w $§ 49$, - elementy butli byłyby uszkodzone (zawór, korozja butli, reduktor),

- stan techniczny instalacji gazowej byłby zły,

- brakowałoby czujnika gazu propan-butan.

W przypadku użytkowania butli gazowych z gazem propan-butan o pojemności $11 \mathrm{~kg} \mathrm{w}$ budynkach wielorodzinnych konieczne powinno być uzyskanie zgody administratora budynku na ich użytkowanie. Natomiast napełnienie przydomowych zbiorników gazu płynnego powinno być możliwe po okazaniu protokołu z okresowego przeglądu instalacji gazowej.

W rozporządzeniu Ministra Infrastruktury w sprawie warunków technicznych, jakim powinny odpowiadać budynki i ich usytuowanie [4], w $§ 177$ znajduje się zapis: „Urządzenia gazowe instalowane w budynku mogą być zasilane gazem płynnym z indywidualnych butli o nominalnej zawartości gazu do $11 \mathrm{~kg}$, pod warunkiem spełnienia następujących wymagań:

1) w jednym mieszkaniu, warsztacie lub lokalu użytkowym nie należy instalować więcej niż dwóch butli,

2) w pomieszczeniu, w którym instaluje się butlę, należy zachować temperaturę niższą niż $35^{\circ} \mathrm{C}$,

3) butlę należy instalować wyłącznie w pozycji pionowej,

4) butlę należy zabezpieczyć przed uszkodzeniami mechanicznymi,

5) między butlą a urządzeniem promieniującym ciepło, z wyłączeniem zestawów urządzeń gazowych z butlami, należy zachować odległość co najmniej 1,5 m,

6) butli nie należy umieszczać w odległości mniejszej niż $1 \mathrm{~m}$ od urządzeń mogących powodować iskrzenie,

7) urządzenia gazowe należy łączyć z reduktorem ciśnienia gazu na butli za pomocą elastycznego przewodu o długości nieprzekraczającej $3 \mathrm{~m}$ i wytrzymałości na ciśnienie co najmniej $300 \mathrm{kPa}$, odpornego na składniki gazu płynnego, uszkodzenia mechaniczne oraz temperaturę do $60^{\circ} \mathrm{C}$,

8) urządzenie gazowe o mocy cieplnej przekraczającej $10 \mathrm{~kW}$ należy łączyć z przewodem elastycznym, o którym mowa w pkt 7, rurą stalową o długości co najmniej $0,5 \mathrm{~m}$ ".

Powyższy zapis proponuje się uzupełnić o kolejne punkty:

1) miejsce instalacji butli gazowej powinno być wyposażone $\mathrm{w}$ detektor gazu propan-butan $\mathrm{z}$ sygnalizacją akustyczną;

2) pomieszczenie, w którym zamontowana jest butla gazowa, powinno posiadać wentylację zlokalizowaną maksymalnie $0,15 \mathrm{~m}$ nad podłogą.

Zaproponowane zapisy spowodują generowanie dodatkowych kosztów dla użytkowników instalacji gazowych na gaz propan-butan, jednak koszty te w porównaniu ze skutkami wystąpienia zdarzeń niepożądanych są pomijalnie małe. Ze 
względu na często powtarzające się przypadki braku właściwej wentylacji dostawcy gazu propan-butan powinni przeprowadzać kampanię uświadamiającą użytkowników butli oraz wpisywać w instrukcji instalowania butli informację o konieczności stosowania detektorów gazu, zgodnie z zaproponowanymi zapisami. Zakup i dystrybucja detektorów przez dostawców gazu wpłynęłyby na obniżenie ceny tych urządzeń.

Ostatnie zagadnienia, które zostały poruszone w niniejszym artykule, dotyczą możliwości wprowadzenia zmian w przepisach związanych ze stosowaniem innych materiałów oraz użytkowaniem, wykonywaniem i kontrolą instalacji gazowych na gaz ziemny.

W rozporządzeniu Ministra Infrastruktury w sprawie warunków technicznych, jakim powinny odpowiadać budynki $\mathrm{i}$ ich usytuowanie [4], w $\S 163$ ust. 4 można rozważyć wprowadzenie zmian: „W budynkach mieszkalnych jednorodzinnych, budynkach w zabudowie zagrodowej i budynkach rekreacji indywidualnej przewody instalacji gazowej, a w pozostałych budynkach tylko przewody za gazomierzami lub odgałęzieniami prowadzącymi do odrębnych mieszkań lub lokali użytkowych, powinny być wykonane z rur, o których mowa w ust. 2, łączonych również z zastosowaniem połączeń gwintowanych, z rur miedzianych łączonych przez lutowanie lutem twardym, $z$ rur wielowarstwowych lub PEX. Dopuszcza się stosowanie innych sposobów łączenia rur, jeżeli spełniają one wymagania szczelności i trwałości określone w Polskiej Normie dotyczącej przewodów gazowych dla budynków. Zastosowanie systemów rur wielowarstwowych lub PEX dozwolone jest przy zainstalowaniu dodatkowych zabezpieczeń, np. zaworów reagujących na podwyższoną temperaturę czy nagły wyciek gazu”.

W związku z proponowanymi zmianami wprowadzonymi do ust. 4 zapisy ust. 5 o brzmieniu: „Po zewnętrznej stronie ścian budynku nie mogą być prowadzone przewody gazowe wykonane:

1) z rur stalowych, jeżeli służą do rozprowadzania paliw gazowych zawierających parę wodną lub inne składniki ulegające kondensacji w warunkach eksploatacyjnych,

2) z rur miedzianych"

proponuje się uzupełnić o dodatkowe punkty:

3) z rur wielowarstwowych,

4) $z$ rur PEX.

Zastosowanie rur wielowarstwowych czy PEX pozwoliłoby na szybkie i łatwe wykonanie instalacji, a w przypadku systemów PEX dodatkowo w instalacji występuje mniej połączeń.

Jeżeli chodzi o zapis w $\S 162$ : „Urządzenia redukcyjne mogą być instalowane wyłącznie na zewnątrz budynku i powinny być zabezpieczone przed dostępem osób niepowołanych i uszkodzeniami mechanicznymi", to w przypadku budynków mieszkalnych proponuje się pozostawić go bez zmian.
Można natomiast rozważyć możliwość zwiększenia ciśnienia w instalacji gazowej i montaż reduktorów przed urządzeniami spalającymi paliwa gazowe w instalacjach przemysłowych, jednak ciśnienie nie powinno przekraczać maksymalnego ciśnienia dopuszczonego Polską Normą [5], a instalację taką należałoby wyposażyć w dodatkowe zawory reagujące na nadmierny przepływ gazu.

Rozdział 7 działu IV rozporządzenia [4] pt.: Instalacja gazowa na paliwa gazowe $\mathrm{w} \S 158$ zawiera zapisy:

- ust. 1: „Instalacje sygnalizujące niedopuszczalny poziom stężenia gazu mogą być stosowane w budynkach, w których jest ustanowiony stały nadzór, zapewniający podejmowanie działań zaradczych, a także w budynkach jednorodzinnych";

- ust. 2: „Czujki sygnalizujące niedopuszczalny poziom stężenia gazu w budynkach, o których mowa w ust. 1, powinny być instalowane w piwnicach i suterenach oraz w pomieszczeniach, w których istnieje możliwość nagromadzenia gazu przy stanach awaryjnych instalacji lub przyłącza gazowego";

- ust. 3: „Sygnały alarmowe stanu zagrożenia wybuchem w budynkach, z wyłączeniem budynków jednorodzinnych, powinny być kierowane do służb lub osób zobowiązanych do podjęcia skutecznej akcji zapobiegawczej”; - ust. 4: „Zabrania się instalowania urządzeń sygnalizacyjno-odcinających dopływ gazu do części mieszkalnej budynku wielorodzinnego. Nie dotyczy to indywidualnych urządzeń sygnalizacyjno-odcinających dopływ gazu do odrębnych mieszkań”;

- ust. 5: „Urządzenia sygnalizacyjno-odcinające dopływ gazu należy stosować w tych pomieszczeniach, w których łączna nominalna moc cieplna zainstalowanych urządzeń gazowych jest większa niż 60 kW";

- ust. 6: „Zawór odcinający dopływ gazu do budynku, będący elementem składowym urządzenia sygnalizacyjno-odcinającego, powinien być instalowany poza budynkiem, między kurkiem głównym a wprowadzeniem przewodu do budynku".

W ust. 4 można rozważyć wprowadzenie zmiany i zezwolić na stosowanie instalacji sygnalizacyjno-odcinających dopływ gazu do części mieszkalnej budynku wielorodzinnego, z zastrzeżeniem, że każde odblokowanie zaworu (elektrozaworu) powinno być wykonane przez osobę upoważnioną, posiadającą odpowiednie kwalifikacje. Po przeprowadzeniu szerokich konsultacji zapisy ust. 5 można by zmienić w taki sposób, aby konieczne było stosowanie instalacji/systemów zabezpieczających we wszystkich budynkach wielorodzinnych mieszkalnych czy przemysłowych.

W budynkach mieszkalnych jednorodzinnych lub pomieszczeniach technicznych należy rozważyć wprowadzenie 
konieczności stosowania prostych detektorów gazu z elektrozaworami odcinającymi dopływ gazu do budynku w każdym pomieszczeniu, gdzie znajduje się urządzenie spalające paliwa gazowe oraz detektorów tlenku węgla w pomieszczeniach wyposażonych w urządzenia spalające paliwa gazowe $\mathrm{z}$ otwartą komorą spalania.

Wszystkie te zmiany poprawiłyby bezpieczeństwo użytkowania instalacji gazowych i zapobiegłyby wielu katastro- fom spowodowanym wybuchem gazu czy zatruciem tlenkiem węgla. Koszty związane z wykonaniem i wyposażeniem budynków w takie systemy/instalacje w porównaniu ze skutkami braku ich stosowania są niskie.

Należy również ożywić i egzekwować przepis z art. 62 ustawy Prawo budowlane [6], nakazujący przeprowadzenie kontroli instalacji gazowych również w budynkach jednorodzinnych.

\section{Podsumowanie}

Wszystkie proponowane zapisy i rozwiązania mają na celu zwiększyć bezpieczeństwo użytkowania paliw gazowych, których popularność wzrasta i co do których powinniśmy przekonywać coraz więcej użytkowników stosujących urządzenia na paliwa stałe. W opinii autora artykułu warto podjąć dyskusję z twórcami prawa budowlanego w zakresie zaproponowanych zmian, jeżeli mogłyby one przyczynić się do urato- wania życia choćby jednej osoby. Dyskusja na temat wprowadzenia zmian w przepisach powinna przebiegać w szerokim gronie specjalistów i ekspertów oraz we współpracy ze służbami odpowiedzialnymi za usuwanie awarii i ratowanie ludzi. Należałoby również włączyć do tej dyskusji dostawców gazu, w szczególności gazu ziemnego, w celu zwiększenia zaufania do marki ,gaz ziemny”.

Prosimy cytować jako: Nafta-Gaz 2017, nr 11, s. 887-893, DOI: 10.18668/NG.2017.11.09

Artykuł nadesłano do Redakcji 8.12.2016 r. Zatwierdzono do druku 30.08.2017 r.

Artykuł powstał na podstawie pracy statutowej pt.: Analiza możliwości poprawy bezpieczeństwa instalacji gazowych - praca INiG - PIB na zlecenie MNiSW; nr zlecenia: 0090/GP/2016, nr archiwalny: DK-4100-81/16.

\section{Literatura}

[1] Orange \& Rockland Pike Country Light \& Power Co.: Natural Gas Installation Standards. Handbook 2015 Edition.

[2] Rataj M.: Ocena wplywu ciagu wstecznego na działanie palnika inżektorowego. Nafta-Gaz 2015, nr 5, s. 320-326.

[3] Wróblewska A.: Ocena możliwości stosowania w instalacjach gazowych systemów rur wielowarstwowych z tworzyw sztucznych. Nafta-Gaz 2010, nr 7, s. 597-601.

\section{Akty prawne i normatywne}

[4] Obwieszczenie Ministra Infrastruktury i Rozwoju z dnia 17 lipca 2015 r. w sprawie ogłoszenia jednolitego tekstu rozporządzenia Ministra Infrastruktury w sprawie warunków technicznych, jakim powinny odpowiadać budynki i ich usytuowanie (Dz.U. z 2015 r., poz. 1422).

[5] PN-EN 1775:2009 Dostawa gazu - Przewody gazowe dla budynków - Maksymalne ciśnienie robocze równe 5 bar lub mniejsze - Zalecenia funkcjonalne.
[6] Rozporządzenie Ministra Spraw Wewnętrznych i Administracji z dnia 16 sierpnia 1999 r. w sprawie warunków technicznych użytkowania budynków mieszkalnych (Dz.U. z 1999 r. $\mathrm{Nr} 74$, poz. 836).

[7] Ustawa z dnia 7 lipca 1994 r. - Prawo budowlane (tekst jednolity Dz.U. z 2016 r., poz. 290).

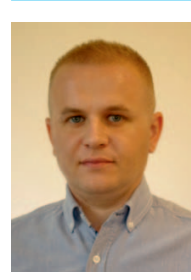

Mgr inż. Tomasz MINOR

Główny specjalista inżynieryjno-techniczny w Zakładzie Przesyłania i Dystrybucji Gazu; Kierownik Laboratorium Badań Armatury i Technik Eksploatacji Gazociągów Instytut Nafty i Gazu - Państwowy Instytut Badawczy ul. Lubicz 25 A, 31-503 Kraków E-mail:tomasz.minor@inig.pl 